\title{
PGPR INDUCED DIFFERENCIAL EXPRESSION OF DEFENCE ENZYMES REGULATING RESISTANCE AGAINST COLLETOTRICHUM CAPSICIIN TURMERIC
}

${ }^{*}$ P. Adhipathi ${ }^{1}$

(adhiagri@gmail.com),

S. Nakkeeran ${ }^{1}$

(nakkeeransingai@yahoo.co.in),

P. Renuka Devi

(renucbe88@gmail.com),

R. Velazhahan ${ }^{1}$

(velazhahan@hotmail.com)

T. Raguchander ${ }^{1}$

(raguchandar@yahoo.com).

${ }^{1}$ Department of Plant Pathology, Centre for Plant Protection Studies,

Tamil Nadu Agricultural University, Coimbatore - 641003, Tamil Nadu, India.

\begin{abstract}
Plant growth promoting Bacillus amyloliquefaciens strain BaTNAU5 and Pseudomonas fluorescens strain Pf3TNAU were evaluated in turmeric for induction defence by differential expression of defence enzymes against Colletotrichum capsici. Further the activity and quantitative assay of the defense enzymes peroxidase (POD), polyphenol oxidase (PPO), phenylalanine ammonia lyase (PAL), $\beta$-1,3-glucanase, chitinase, catalase and defense-inducing chemicals (total phenols) significantly increased with soil and foliar application of $B$. amyloliquefaciens (BaTNAU5) and $P$. fluorescens (Pf3TNAU). Western blot analysis of protein extracts from B. amyloliquefaciens (BaTNAU5) and $P$. fluorescens (Pf3TNAU) challenged with $C$. capsici, a chitinase with an apparent molecular weight of $28 \mathrm{kDa}$ was induced four days after treatment.
\end{abstract}

\section{Keywords}

B. amyloliquefaciens; peroxidise; polyphenol oxidase; chitinase; $\beta$-1,3-glucanase; induced resistance.

\section{Academic Discipline And Sub-Disciplines}

Molecular Plant Pathology.

\section{SUBJECT CLASSIFICATION}

Plant Pathology.

\section{TYPE (METHOD/ APPROACH)}

Quasi - Experimental.

\section{Council for Innovative Research}

\section{Peer Review Research Publishing System}

\section{Journal: JOURNAL OF ADVANCES IN BIOTECHNOLOGY}

Vol . 4, No. 2.

www.cirjbt.org , jbteditor@gmail.com 


\section{INTRODUCTION}

Turmeric (Curcuma longa L) is known as "golden spice" and one of the most important spice crops in tropical and subtropical countries. The underground rhizomes are rich in "curcumin", which is traditionally used for medicinal, religious, culinary purposes, cosmetic and dye. India is the world largest producer of turmeric which has the total area of cultivation under 195.07 thousand ha with the total production of 992.94 thousand tonnes. India contributes $80 \%$ of the world turmeric production and $60 \%$ to the total trade with $36.99 \%$ exports [1]. Leaf spot caused by Colletotrichum capsici [(Syd.) Butler \& Bisby] is the most important disease causing extensive yield losses upto $62 \%$ to the turmeric production [2]. Management of turmeric leaf spot disease has been exclusive use of chemical pesticides which effectively eradicate the $C$. capsici. Although, several effective systemic fungicides recommended against $C$. capsici, they are not considered to be long-term solutions due to development of fungicide resistance [3], fungicide residues, toxicity to non-target organisms and environmental hazards. Therefore, recent efforts have been made on developing eco-friendly safe, long lasting and viable methods which effective against plant pathogens for the management of plant diseases. The use of biocontrol agents has been shown to be eco-friendly and effective against many plant pathogens and pest. Several biocontrol agents have been documented to prevent plant diseases by inducing systemic resistance (ISR) in plants. ISR is associated with the rapid accumulation of the same structurally unrelated putative defense compounds. It has been suggested that cultivar (race) specific resistance is initiated by the specific interaction of a pathogen induced product or elicitor and plant receptor. Plant growth promoting rhizobacteria (PGPR) are capable of stimulating different defense mechanisms that leads to systemic disease protection in plants [4].

The induction of pathogenesis-related (PR) proteins is mediated by various signalling molecules or elicitors or (PR) proteins gene expression in the plants. The expression of defence enzymes and PR proteins in plants avoids or evades the virulent pathogen to infect the host which can trigger the elicitors there by enhance the resistance reaction and activate the defences [5]. These defence gene or elicitor products includes peroxidase (PO), polyphenol oxidase (PPO) that catalyze the formation of lignin deposition on the cell wall which can restrict penetration peg of fungus in pathogenesis [6]. Phenylanine ammonia lyase is an enzyme that catalyzes a reaction coverting L-phenylalanine to ammonia and transcinnamic acid in the phenyl propanoid pathway which directly involve in the biosynthesis of the polyphenol compounds such as flavanoids, phenylpropanoids and lignin in plants [7]. The activity of PAL is induced dramatically in response to various stimuli such as tissue wounding, pathogenic attack. PR proteins like chitinases and $\beta-1,3$ glucanase [8] have potential antifungal activity which degrade the fungal cell wall and cause lysis of fungal cells. The chitin and glucan oligomers released during degradation of fungal cell wall act as elicitors that elicit various defence mechanisms in the plants. Constitutive expression of the PR proteins and defence related enzymes in crop plants can enhance induced systemic resistance against invading pathogen [9]. Mixtures of plant growth promoting rhizobacteria has documented with induction of systemic resistance against multiple plant diseases [10]. The production of siderophores and iron chelating agents on the Pseudomonas mediated antagonism against Colletotrichum falcatum in sugarcane [11]. Keeping the above facts with induced resistance, the present study planned to investigate induction of various defense related genes encoding proteins implicated in strengthening of plant cell walls by antagonistic bacteria florescent pseudomonas and Bacillus in response to challenged infection of $C$. capsici.

\section{MATERIALS AND METHODS}

\section{Plant Materials, Bioagents and Pathogen}

Susceptible turmeric cultivar Erode Local-8 was used in the experiments for evaluating the differential expression plant defence enzymes induced by $B$. amyloliquefaciens (BaTNAU5) and $P$. fluorescens (Pf3TNAU) against turmeric leaf spot disease. The endophytic $B$. amyloliquefaciens (BaTNAU5) and $P$. fluorescens (Pf3TNAU) strains were isolated from healthy turmeric plants. The bacterial colonies were identified on the basis of their morphology, gram reaction and DNA sequence. The virulent leaf spot pathogen was isolated from turmeric plants showing typical leaf spot symptom. Single spore isolation was followed to obtain a pure culture of pathogen. The isolates were identified based on morphological and cultural charactertics of pathogens [12].

\section{Detection of Induced Defense Enzymes}

The healthy turmeric plants was pretreated with B. amyloliquefaciens (BaTNAU5) and P. fluorescens (Pf3TNAU) cell suspension or the cell-free filtrate, 5 days before challenged with $C$. capsici on 50 days old plants. The leaves of PGPR strains and $C$. capsici treated plants were collected for the estimation of defence related enzymes. The leaf samples were collected at $0,2,4,6,8,10$ and 12 days for 2 days interval for the determination of peroxidase (POD), polyphenol oxidase (PPO) and phenylalanine ammonia lyase (PAL) activities according to [13]. In brief, $1 \mathrm{~g}$ of leaf tissue was frozen in liquid nitrogen then homogenized in $10 \mathrm{ml}$ of icecold $50 \mathrm{mM}$ potassium phosphate buffer $(\mathrm{pH} 6.8)$ containing $1 \mathrm{M} \mathrm{NaCl}, 1 \%$ polyvinylpyrrolidone, $1 \mathrm{mM}$ EDTA and $10 \mathrm{mM} \beta$-mercaptoethanol. The homogenates were filtered and centrifuged at $8000 \mathrm{rpm}$ at $4^{\circ} \mathrm{C}$ for $25 \mathrm{~min}$. The supernatants were used for determination of enzyme activities and protein content. Each treatment consisted of three replicates and three spectrophotometric readings using a ELICO Double Beam SL210 UVVIS spectrophotometer. The protein concentration in the supernatant was determined according to the method of [14] using bovine serum albumin as a standard.

\section{Peroxidase Isozyme (POD) Analysis:}

The POD enzyme activity was determined by measuring the increased in absorbance due to oxidation of guaiacol to tetraguaiacol at $470 \mathrm{~nm}$. Peroxidase isozymes were analyzed as per the procedure described by [15]. The enzyme 
extract was prepared by homogenizing one gram of leaf sample in $5 \mathrm{ml}$ of $0.1 \mathrm{M}$ phosphate buffer, $\mathrm{pH} 7.0$ in a chilled pestle and mortar. The homogenate was centrifuged at $12,000 \mathrm{rpm}$ at $4^{\circ} \mathrm{C}$ for $20 \mathrm{~min}$ and supernatant obtained was used for PO isozyme analysis.

\section{Polyphenol Oxidase Isozyme (PPO) Analysis}

PPO activity was determined by monitoring the increase in absorbance at $400 \mathrm{~nm}$ due to oxidation of catechol [16]. One unit of PPO enzyme activities was defined as a change in absorbance of 0.01 under the assay conditions and enzyme activity was expressed as total activity units per $1 \mathrm{mg}$ of protein ( $\mathrm{U} \mathrm{mg}$ protein).

\section{Phenylanine Ammonia Lyase (PAL) Analysis}

PAL activity was determined following the direct spectrophotometric method adapted by [17] using phenylalanine as a substrate. One unit of PAL activity represented the amount of enzyme catalyzing the formation of 1 nmol of cinnamic acid in $1 \mathrm{~min}$. PAL activity was expressed as total activity units per $1 \mathrm{mg}$ of protein $\left(\mathrm{U} \mathrm{mg}\right.$ protein $\left.{ }^{-1}\right)$.

\section{$\beta-1,3-G l u c a n a s e$}

$\beta$-1,3-glucanase enzyme activity was colorimetrically determined by the method developed by [18] Pan et al., 1991. The crude enzyme extract $(62.5 \mu \mathrm{l})$ was added with $4 \%$ laminarin and incubated at $40^{\circ} \mathrm{C}$ for $10 \mathrm{~min}$. The reaction was stopped by adding $375 \mu \mathrm{l}$ of dinitrosalicylic acid $(300 \mathrm{ml}$ of $4.5 \% \mathrm{NaOH}$ to $880 \mathrm{ml}$ containing $8.8 \mathrm{~g}$ of DNS and $22.5 \mathrm{~g}$ potassium sodium tartrate) and warming for $5 \mathrm{~min}$ in a boiling water bath. The resulting coloured solutions absorbance was recorded at $500 \mathrm{~nm}$. The prepared crude extract with laminarin at initial incubation served as control. The enzyme activity was expressed as $\mu \mathrm{g}$ equivalents of glucose $\mathrm{min}^{-1} \mathrm{~g}^{-1}$ fresh weight

\section{Superoxide Dismutase (SOD) Isoform Analysis}

Superoxide dismutase (SOD) enzyme activity was assayed and expressed in SOD units mg 1 tissue (50\% NBT inhibition $1 / 41$ unit) [19]. The native PAGE gel in transferred into $0.05 \mathrm{M}$ potassium phosphate buffer $(\mathrm{pH}-7.8)$ and solution was equipped with pinch of NBT $(0.1 \mathrm{mM})$ and riboflavin $(0.05 \mathrm{mM})$. Then $200 \mu \mathrm{l}$ of TEMED $(0.3 \% \mathrm{v} / \mathrm{v})$ was added and incubated in dark for $30 \mathrm{~min}$. Then the gel was exposed to UV light for reaction and development bands and photographed.

\section{Estimation of Total Phenolic Content}

The total phenolic content present in the leaves was estimated following [20] Bray and Thorpe method. Turmeric leaves $(1 \mathrm{~g})$ were frozen in liquid nitrogen which ground to fine powder and extracted in $10 \mathrm{ml}$ of $80 \%$ methanol for 15 min at $70^{\circ} \mathrm{C}$. Then $250 \mu \mathrm{l}$ of Folin-Ciocalteau reagent $(1 \mathrm{M})$ and $5 \mathrm{ml}$ of distilled water were added with one ml of the methanolic extract and solution was incubated at $25^{\circ} \mathrm{C}$. After $3 \mathrm{~min} 1 \mathrm{ml}$ of $\mathrm{Na} 2 \mathrm{CO} 3$ a saturated solution was added and the reaction mixture was incubated at $25^{\circ} \mathrm{C}$ for $1 \mathrm{~h}$. The intensity of the developed blue colour was measured at $725 \mathrm{~nm}$ using a Beckman DU64 spectrophotometer (Beckman Instruments Inc., California, USA). The content of the total soluble phenols was calculated based on a standard curve obtained from a Folin-Ciocalteau reaction with phenol and expressed as phenol equivalents in $\mu \mathrm{g} g-1$ fresh mass.

\section{Catalase}

Catalase activity was estimated following [21] Dekock et al method. One $\mathrm{g}$ of turmeric leaf was homogenized with $10 \mathrm{ml}$ of ice cold $0.067 \mathrm{M}$ phosphate buffer $(\mathrm{pH} \mathrm{7.0)}$ and centrifuged and extract used as source for catalase. Then $0.03 \mathrm{ml}$ of enzyme extract was mixed with $3 \mathrm{ml}$ of hydrogen peroxide - phosphate buffer which used as reaction mixture. The absorbance value was recorded immediately with an interval of 10 or $20 \mathrm{~s}$. The required time for absorbance was decrease from 0.45 to 0.4 was recorded and catalase activity was expressed as units $\mathrm{g}^{-1}$ tissue.

\section{Native Polyacrylamide Gel Electrophoresis Analysis}

The peroxidase and polyphenol oxidase isoform profiles were determined by discontinuous native polyacrylamide gel electrophoresis analysis (PAGE) [22]. The protein extract was prepared by homogenizing $1 \mathrm{~g}$ of leaf sample in $2 \mathrm{ml}$ of $0.1 \mathrm{M}$ sodium phosphate buffer $(\mathrm{pH} 7.0)$ and centrifuged at $18,000 \mathrm{rpm}$ for $20 \mathrm{~min}$ at $4^{\circ} \mathrm{C}$. The protein content of the sample was determined [14] and samples (50 lg protein) were loaded into $8 \%$ polyacrylamide gels (Sigma, USA). The samples were electrophoresis in $12 \%$ polyacrylamide gels (Sigma, USA), after that PO isoforms were visualized by soaking the gels in staining solution containing $0.05 \%$ benzidine (Sigma-Aldrich, Mumbai, India) and $0.03 \% \mathrm{H} 2 \mathrm{O} 2 \mathrm{in}$ acetate buffer $(20 \mathrm{mM}, \mathrm{pH}$ 4.2) (Nadolny and Sequeira 1980). For assessing the PPO isoform profiles, the gels were equilibrated for $30 \mathrm{~min}$ in $0.1 \% \mathrm{p}$-phenylene diamine, followed by the addition of $10 \mathrm{mM}$ catechol in the same buffer [23].

\section{Western Blot Analysis}

Proteins were extracted from control, PGPR treated and challenged with $C$. capsici turmeric leaves by grinding $1 \mathrm{~g}$ of tissues with $5 \mathrm{ml}$ of $0.1 \mathrm{M}$ phosphate buffer, $\mathrm{pH} 6.5$ containing $0.5 \mathrm{mM}$ phenylmethylsulphonyl fluoride as described by Velazhahan et al. (1998). Proteins $(100 \mu \mathrm{g})$ in aliquots of extracts were separated on $12 \%$ SDS-PAGE [22] and electroblotted onto polyvinylene difluoride (PVDF) membrane (pore size $0.45 \mu \mathrm{m}$, Bio- Rad) using BioRad semidry transfer cell in accordance with the manufacturer's instructions. Western blotting was carried out as described by [24] Winston et al. (1987) with an antiserum raised against barley chitinase. The barley chitinase antiserum was a gift from Dr. R. Velazhahan, Department of Plant Pathology, Tamil Nadu Agricultural University, Coimbatore, India. Apparent molecular 
mass of proteins was determined by comparison with molecular weight standards (Rainbow markers, Amersham Pharmacia, USA). Protein concentrations were determined by Bradford assay [14].

\section{Statistical Analysis}

The glasshouse trial data analyzed using IRRISTAT version 92.1 programme developed by the biometric unit, International Rice Research Institute, the Philippines. The quantitative assay of defence enzymes in treatment means were compared by Duncan'smultiple range test (DMRT) [25].

\section{RESULTS}

\section{Induction of Defense Related Enzymes in Turmeric Against C. Capsici}

Induction of biochemical defence was analysed through biochemical and molecular analysis which revealed the increased activity of peroxidase, polyphenol oxidase phenylalanine ammonialyase, catalase, $\beta-1,3$ glucanase and phenols in turmeric plants.

\section{Peroxidase (POD)}

The activity of peroxidase (PO) increased in the cell suspension of $B$. amyloliquefaciens (BaTNAU5) $+P$. fluorescens (Pf3TNAU) treated plants challenged with the pathogen. The two fold increased PO activity (1.237) was recorded on the fourth day after challenged inoculation and the activity was retained at higher levels throughout the experimental period. Plants inoculated with the pathogen alone had comparatively less PO activity $(0.671)$. The plants treated with cell suspension of $B$. amyloliquefaciens and $P$. fluorescens alone also recorded a significant variation in the induction of $\mathrm{PO}$ activity during the experimental period, but the activity was lesser than the PGPR treated plants challenged with the pathogen (Table 1).

Table 1. Induction of peroxidase activity in turmeric plants upon treatment with endophytic PGPRs strains challenged with $C$. capsici under glass house conditions

\begin{tabular}{|c|c|c|c|c|c|c|c|}
\hline & \multicolumn{6}{|c|}{ Change in absorbance $(420 \mathrm{~nm})^{\star} / \mathrm{min} / \mathrm{g}$ fresh tissue } \\
\hline & & \multirow{3}{*}{0 -Day } & \multirow{3}{*}{$\begin{array}{l}\text { 2- Day } \\
0.348^{d}\end{array}$} & \multirow{3}{*}{$\begin{array}{l}\text { 4-Day } \\
0.879^{d}\end{array}$} & \multirow{3}{*}{$\begin{array}{l}6 \text { - Day } \\
0.695^{\mathrm{e}}\end{array}$} & \multirow{3}{*}{$\begin{array}{l}\text { 8- Day } \\
0.601^{d}\end{array}$} & \multirow{3}{*}{$\begin{array}{l}\text { 10-day } \\
0.562^{c}\end{array}$} \\
\hline & & & & & & & \\
\hline T1 & $\begin{array}{l}\text { Pretreated with cell suspension of } B \text {. amyloliquefaciens } \\
\text { (BaTNAU5) + Pathogen }-(R D+S D+F A)^{*}\end{array}$ & & & & & & \\
\hline T2 & $\begin{array}{l}\text { Pretreated with cell suspension of } B \text {. amyloliquefaciens } \\
\text { (BaTNAU5) - (RD+SD+FA)* }\end{array}$ & $0.305^{\mathrm{b}}$ & $0.339^{d}$ & $0.814^{d}$ & $0.793^{\mathrm{d}}$ & $0.643^{\mathrm{cd}}$ & $0.576^{\mathrm{c}}$ \\
\hline T3 & $\begin{array}{l}\text { Pretreated with cell suspension of } P . \text { fluorescens } \\
(\text { Pf3TNAU })+\text { Pathogen }-(R D+S D+F A)^{*}\end{array}$ & $0.391^{\mathrm{a}}$ & $0.438^{\mathrm{C}}$ & $1.045^{\mathrm{C}}$ & $0.974^{b}$ & $0.735^{\mathrm{b}}$ & $0.710^{b}$ \\
\hline T4 & $\begin{array}{l}\text { Pretreated with cell suspension of } P \text {. fluorescens } \\
\text { (Pf3TNAU) }-(\mathrm{RD}+\mathrm{SD}+\mathrm{FA})^{*}\end{array}$ & $0.271^{\mathrm{C}}$ & $0.356^{d}$ & $0.967^{c}$ & $0.864^{c}$ & $0.683^{\mathrm{bc}}$ & $0.497^{d}$ \\
\hline T5 & $\begin{array}{l}\text { Pretreated with cell suspensions of } B \text {. amyloliquefaciens } \\
(\text { BaTNAU5) + P. fluorescens (Pf3TNAU) +Pathogen - } \\
(\mathrm{RD}+\mathrm{SD}+\mathrm{FA})^{*}\end{array}$ & $0.420^{\mathrm{a}}$ & $0.546^{\mathrm{b}}$ & $1.237^{\mathrm{a}}$ & $1.054^{\mathrm{a}}$ & $0.845^{\mathrm{a}}$ & $0.802^{\mathrm{a}}$ \\
\hline T6 & $\begin{array}{l}\text { Pretreated with cell suspensions of } B \text {. amyloliquefaciens } \\
\text { (BaTNAU5) + P. fluorescens (Pf3TNAU) -(RD+SD+FA) }\end{array}$ & $0.410^{\mathrm{a}}$ & $0.621^{\mathrm{a}}$ & $1.146^{\mathrm{b}}$ & $1.013^{\mathrm{ab}}$ & $0.734^{\mathrm{b}}$ & $0.691^{b}$ \\
\hline T7 & Pathogen inoculated control & $0.253^{\mathrm{C}}$ & $0.352^{\mathrm{d}}$ & $0.671^{\mathrm{e}}$ & $0.486^{\dagger}$ & $0.436^{\mathrm{e}}$ & $0.397^{\mathrm{e}}$ \\
\hline T8 & Healthy control & $0.212^{\mathrm{d}}$ & $0.293^{\mathrm{e}}$ & $0.414^{\dagger}$ & $0.362^{g}$ & $0.343^{\dagger}$ & $0.311^{\dagger}$ \\
\hline
\end{tabular}

${ }^{*} \mathrm{RD}$ - Rhizome dipping, SD- Soil drenching, FA- Foliar application. *Values are the mean of three replications. In a column, means followed by common letters are not significantly different at the $5 \%$ level by DMRT.

\section{Polyphenol Oxidase (PPO)}

The increased activity of PPO was recorded in the cell suspension of $B$. amyloliquefaciens (BaTNAU5) $+P$. fluorescens (Pf3TNAU) treated plants challenged with the pathogen. The maximum PPO activity (2.782) was recorded on sixth day after challenged inoculation and the activity retained at higher levels throughout the experimental period. The three fold increased PPO activity was recorded in cell suspension of $B$. amyloliquefaciens $+P$. fluorescens treated plants challenged with the pathogen, and was statistically significant than other treatments. The challenged inoculation with pathogen alone had comparatively less PPO activity (0.978). The plants treated with cell suspension of $B$. amyloliquefaciens and $P$. fluorescens alone were inferior in the induction of PPO activity during the experimental period compared to the baccterized plants challenged with the pathogen. However, the induction was higher when compared with control (Table 2). 
Table 2. Induction of polyphenol oxidase activity in turmeric plants upon treatment with endophytic PGPRs strains challenged with $C$. capsici under glass house conditions

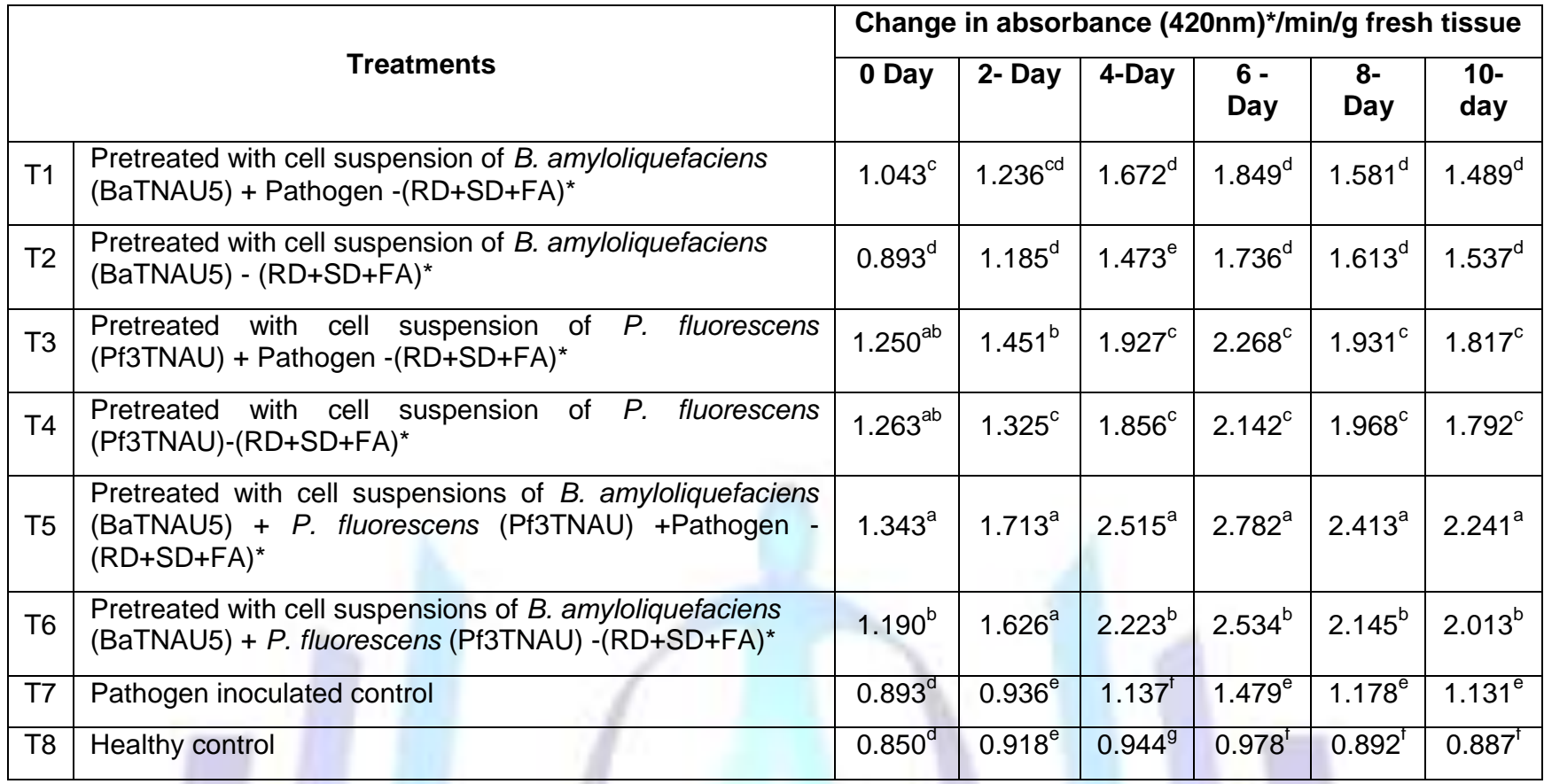

${ }^{*} \mathrm{RD}$ - Rhizome dipping, SD- Soil drenching, FA- Foliar application. *Values are the mean of three replications. In a column, means followed by common letters are not significantly different at the $5 \%$ level by DMRT.

\section{Phenylalanine Ammonia Lyase (PAL)}

The induction of phenylalanine ammonia lyase (PAL) increased after second day of the pathogen inoculation and reached maximum on the sixth day after challenge inoculation with the pathogen. Three fold increase of PAL activity (6.420) was recorded in cell suspension of $B$. amyloliquefaciens (BaTNAU5) $+P$. fluorescens (Pf3TNAU) treated plants when compared with control. Similarly, plants were inoculated with the pathogen alone recorded increased activity of PAL but the induction of activity (2.230) was observed for $4^{\text {th }}$ and $6^{\text {th }}$ days, there after declined drastically. Turmeric plants treated with $B$. amyloliquefaciens and $P$. fluorescens alone also had significantly higher PAL activity compared with untreated control but activity was less compared with challengeinoculated plants (Table 3).

Table 3. Induction of phenylalanine ammonia lyase activity in turmeric plants upon treatment with endophytic PGPRs strains challenged with $C$. capsici under glass house conditions

\begin{tabular}{|c|c|c|c|c|c|c|c|}
\hline & \multicolumn{6}{|c|}{ n mol transcinnamic acid ${ }^{*} / \mathrm{min} / \mathrm{g}$ fresh tissue } \\
\hline & & 0 Day & 2- Day & 4-Day & $\begin{array}{l}6- \\
\text { Day }\end{array}$ & $\begin{array}{l}\text { 8- } \\
\text { Day }\end{array}$ & $\begin{array}{l}\text { 10- } \\
\text { day }\end{array}$ \\
\hline T1 & $\begin{array}{l}\text { Pretreated with cell suspension of } B \text {. amyloliquefaciens } \\
\text { (BaTNAU5) + Pathogen }-(R D+S D+F A)^{*}\end{array}$ & $1.791^{\mathrm{cd}}$ & $2.610^{\mathrm{C}}$ & $4.670^{b}$ & $5.120^{b}$ & $4.630^{b}$ & $3.980^{b}$ \\
\hline T2 & $\begin{array}{l}\text { Pretreated with cell suspension of } B \text {. amyloliquefaciens } \\
\text { (BaTNAU5) - (RD+SD+FA)* }\end{array}$ & $2.240^{\mathrm{a}}$ & $2.510^{\mathrm{cd}}$ & $3.410^{d}$ & $4.270^{\mathrm{C}}$ & $3.720^{d}$ & $3.530^{\mathrm{C}}$ \\
\hline T3 & $\begin{array}{l}\text { Pretreated with cell suspension of } P . \text { fluorescens } \\
\left(\text { Pf3TNAU) + Pathogen }-(R D+S D+F A)^{*}\right.\end{array}$ & $2.172^{\mathrm{a}}$ & $2.541^{\mathrm{cd}}$ & $4.100^{\mathrm{C}}$ & $4.920^{b}$ & $4.630^{\mathrm{b}}$ & $4.321^{\mathrm{b}}$ \\
\hline T4 & $\begin{array}{l}\text { Pretreated with cell suspension of } P . \text { fluorescens } \\
\text { (Pf3TNAU)-(RD+SD+FA)* }\end{array}$ & $1.837^{\mathrm{bcd}}$ & $2.430^{\text {cde }}$ & $3.450^{d}$ & $4.690^{\mathrm{b}}$ & $4.180^{\mathrm{C}}$ & $3.970^{b}$ \\
\hline T5 & $\begin{array}{l}\text { Pretreated with cell suspensions of } B \text {. amyloliquefaciens } \\
(\text { BaTNAU5) + P. fluorescens (Pf3TNAU) +Pathogen - } \\
(\mathrm{RD}+\mathrm{SD}+\mathrm{FA})^{*}\end{array}$ & $1.978^{\mathrm{b}}$ & $3.128^{\mathrm{a}}$ & $4.870^{\mathrm{ab}}$ & $6.420^{\mathrm{a}}$ & $5.610^{\mathrm{a}}$ & $5.420^{\mathrm{a}}$ \\
\hline T6 & $\begin{array}{l}\text { Pretreated with cell suspensions of } B \text {. amyloliquefaciens } \\
\text { (BaTNAU5) + P. fluorescens (Pf3TNAU) }-(\mathrm{RD}+\mathrm{SD}+\mathrm{FA})^{*}\end{array}$ & $1.678^{\mathrm{d}}$ & $2.841^{b}$ & $5.164^{\mathrm{a}}$ & $6.120^{\mathrm{a}}$ & $5.612^{\mathrm{a}}$ & $5.630^{\mathrm{a}}$ \\
\hline T7 & Pathogen inoculated control & $1.759^{\text {cd }}$ & 2.250 & $2.956^{\mathrm{e}}$ & $3.450^{\mathrm{d}}$ & $3.140^{\mathrm{e}}$ & $2.800^{\mathrm{d}}$ \\
\hline T8 & Healthy control & $1.923^{\mathrm{DC}}$ & $2.342^{\mathrm{de}}$ & $2.456^{\top}$ & $2.230^{e}$ & $2.150^{\top}$ & $2.150^{\mathrm{e}}$ \\
\hline
\end{tabular}


${ }^{*} \mathrm{RD}$ - Rhizome dipping, SD- Soil drenching, FA- Foliar application. *Values are the mean of three replications. In a column, means followed by common letters are not significantly different at the $5 \%$ level by DMRT.

\section{$\beta-1$, 3-Glucanase}

The induction of $\beta-1,3$ glucanase was maximum in PGPRs treated rhizome challenged with the pathogen and higher activities were observed at sixth and eighth days after challenged inoculation. The 2.2 fold increase of $\beta-1,3$ glucanase activity (201.96) was recorded in cell suspension of $B$. amyloliquefaciens $+P$. fluorescens treated plants was statistically significant and superior compared with healthy control. In plants inoculated with the pathogen alone, the enzyme activity (94.35\%), increased initially but later declined drastically (Table 4).

Table 4. Induction of $\beta-1,3-g l u c a n a s e$ activity in turmeric plants upon treatment with endophytic PGPRs strains challenged with $C$. capsici under glass house conditions

\begin{tabular}{|c|c|c|c|c|c|c|c|}
\hline \multirow{2}{*}{\multicolumn{2}{|c|}{ Treatments }} & \multicolumn{6}{|c|}{$\mu \mathrm{g}$ of glucose ${ }^{\star} / \mathrm{min} / \mathrm{g} /$ fresh tissue } \\
\hline & & \multirow{2}{*}{$\begin{array}{l}\text { O Day } \\
88.36^{a}\end{array}$} & \multirow{2}{*}{$\begin{array}{c}\text { 2- Day } \\
109.48^{b c}\end{array}$} & \multirow{2}{*}{ 4-Day } & \multirow{2}{*}{$\begin{array}{l}6 \text { - Day } \\
150.56^{d}\end{array}$} & \multirow{2}{*}{$\begin{array}{c}\text { 8- Day } \\
161.96^{\text {bc }}\end{array}$} & \multirow{2}{*}{$\begin{array}{l}10 \text {-day } \\
100.90^{\circ}\end{array}$} \\
\hline $\mathrm{T} 1$ & $\begin{array}{l}\text { Pretreated with cell suspension of } B \text {. } \\
\text { amyloliquefaciens (BaTNAU5) + Pathogen - } \\
(\mathrm{RD}+\mathrm{SD}+\mathrm{FA})^{*}\end{array}$ & & & & & & \\
\hline T2 & $\begin{array}{l}\text { Pretreated with cell suspension of } B . \\
\text { amyloliquefaciens (BaTNAU5) - (RD+SD+FA)* }\end{array}$ & $91.20^{\mathrm{a}}$ & $99.04^{d}$ & $121.84^{\mathrm{cd}}$ & $140.08^{d}$ & $151.52^{\mathrm{cd}}$ & $115.80^{c}$ \\
\hline T3 & $\begin{array}{l}\text { Pretreated with cell suspension of } P \text {. fluorescens } \\
\text { (Pf3TNAU) + Pathogen }-(R D+S D+F A)^{*}\end{array}$ & $79.32^{b}$ & $102.08^{\mathrm{cd}}$ & $122.12^{\mathrm{cd}}$ & $164.32^{c}$ & $141.36^{\text {de }}$ & $140.52^{b}$ \\
\hline $\mathrm{T} 4$ & $\begin{array}{l}\text { Pretreated with cell suspension of } P \text {. fluorescens } \\
(\text { Pf3TNAU)-(RD+SD+FA)* }\end{array}$ & $79.96^{b}$ & $102.60^{\mathrm{cd}}$ & $114.92^{d}$ & $144.88^{d}$ & $134.36^{\mathrm{e}}$ & $133.72^{b}$ \\
\hline T5 & $\begin{array}{l}\text { Pretreated with cell suspensions of } B . \\
\text { amyloliquefaciens (BaTNAU5) }+P \text {. fluorescens } \\
\text { (Pf3TNAU) +Pathogen }-(\mathrm{RD}+\mathrm{SD}+\mathrm{FA})^{*}\end{array}$ & $91.20^{\mathrm{a}}$ & $134.04^{\mathrm{a}}$ & $162.12^{\mathrm{a}}$ & $201.96^{\mathrm{a}}$ & $192.44^{a}$ & $182.48^{\mathrm{a}}$ \\
\hline T6 & $\begin{array}{l}\text { Pretreated with cell suspensions of } B \text {. } \\
\text { amyloliquefaciens (BaTNAU5) }+P \text {. fluorescens } \\
\text { (Pf3TNAU) }-(\mathrm{RD}+\mathrm{SD}+\mathrm{FA})^{*}\end{array}$ & $84.24^{\mathrm{ab}}$ & $112.96^{b}$ & $137.88^{b}$ & $188.28^{b}$ & $170.44^{b}$ & $172.48^{\mathrm{a}}$ \\
\hline T7 & Pathogen inoculated control & $61.20^{c}$ & $84.12^{\mathrm{e}}$ & $92.40^{\mathrm{e}}$ & $94.35^{\mathrm{e}}$ & $85.26^{\dagger}$ & $63.16^{\mathrm{e}}$ \\
\hline T8 & Healthy control & $65.24^{\mathrm{C}}$ & $68.25^{\dagger}$ & $73.64^{\dagger}$ & $71.65^{\dagger}$ & $69.08^{9}$ & $49.64^{\dagger}$ \\
\hline
\end{tabular}

${ }^{*} \mathrm{RD}$ - Rhizome dipping, SD- Soil drenching, FA- Foliar application. *Values are the mean of three replications. In a column, means followed by common letters are not significantly different at the $5 \%$ level by DMRT.

\section{Superoxide Dismutase (SOD)}

The activity of SOD increased in the cell suspension of B. amyloliquefaciens (BaTNAU5) + Pseudomonas fluorescens (Pf3TNAU) treated rhizome plants challenged with the pathogen. The SOD activity increased from second day and reached maximum at fourth day after challenge inoculation with the 3.5 fold increased activity (17.64). Plants inoculated with the pathogen alone had comparatively less SOD activity (5.09). The plants treated with cell suspension of $B$. amyloliquefaciens and $P$. fluorescens alone also recorded the significant variation in the induction of SOD activity, but it was comparatively lower than the bacterized and challenged plants (Table 5). 
Table 5. Induction of super oxide dismutase activity in turmeric plants upon treatment with endophytic PGPRs strains challenged with $C$. capsici under glass house conditions

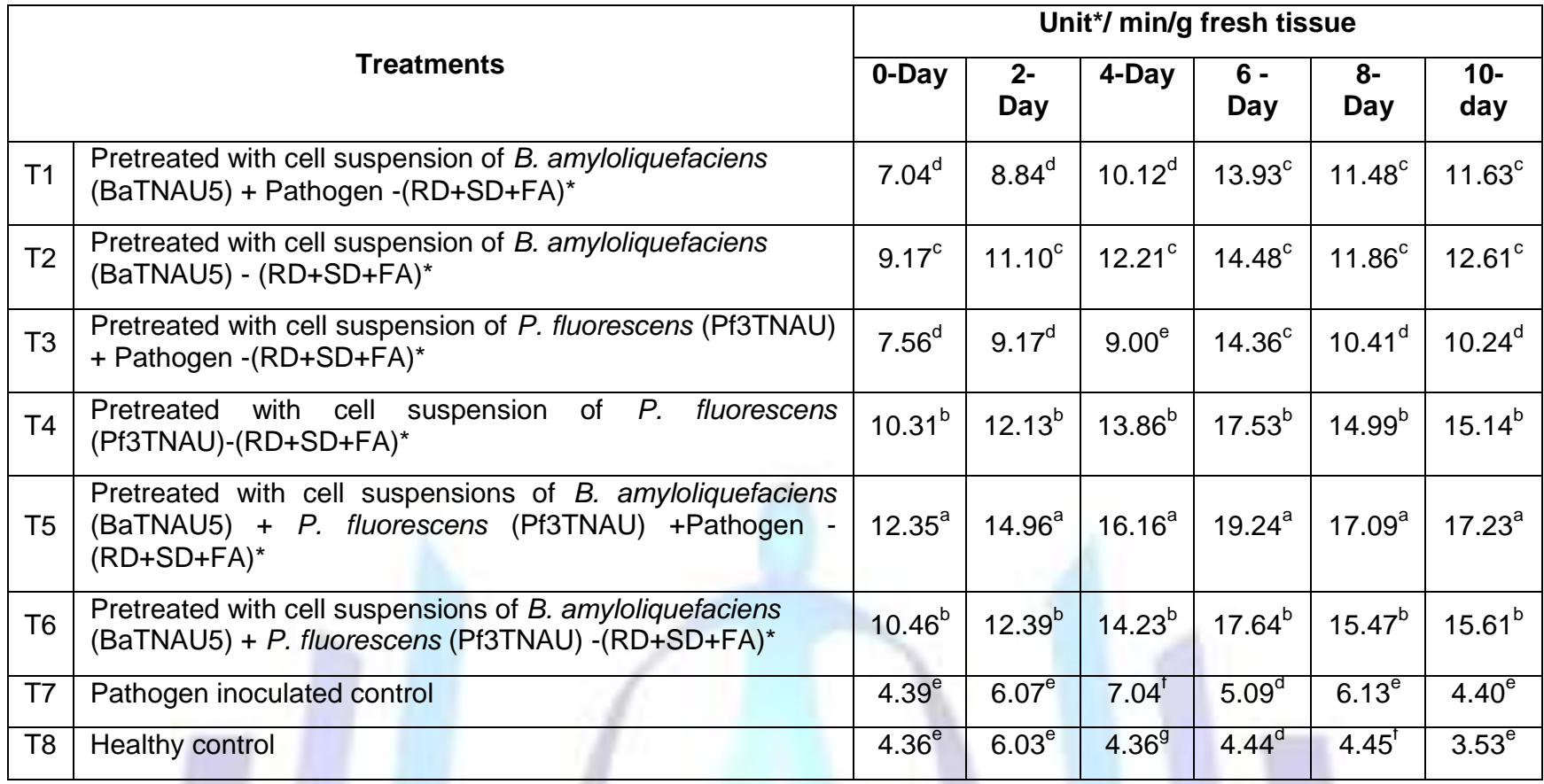

${ }^{*} \mathrm{RD}$ - Rhizome dipping, SD- Soil drenching, FA- Foliar application. *Values are the mean of three replications. In a column, means followed by common letters are not significantly different at the $5 \%$ level by DMRT.

\section{Total Phenols}

Studies on induction of defense mechanisms revealed that higher accumulations of phenolics were observed in both cell suspensions of $B$. amyloliquefaciens $+P$. fluorescens bacterised turmeric plants challenge inoculated with $C$. capsici. Accumulation of phenolics started to increase after second day of challenge inoculation. The maximum accumulation was observed on the sixth day (595.20) after challenge inoculation. Plants inoculated with the pathogen alone also recorded increased accumulation of phenolics, but accumulation started on the second day after pathogen inoculation and drastically declined (335.46). There was no marked change in the activity of phenols in plants treated with $B$. amyloliquefaciens and $P$. fluorescens (Table 6).

Table 6. Induction of total phenol activity in turmeric plants upon treatment with endophytic PGPRs strains challenged with $C$. capsici under glass house conditions

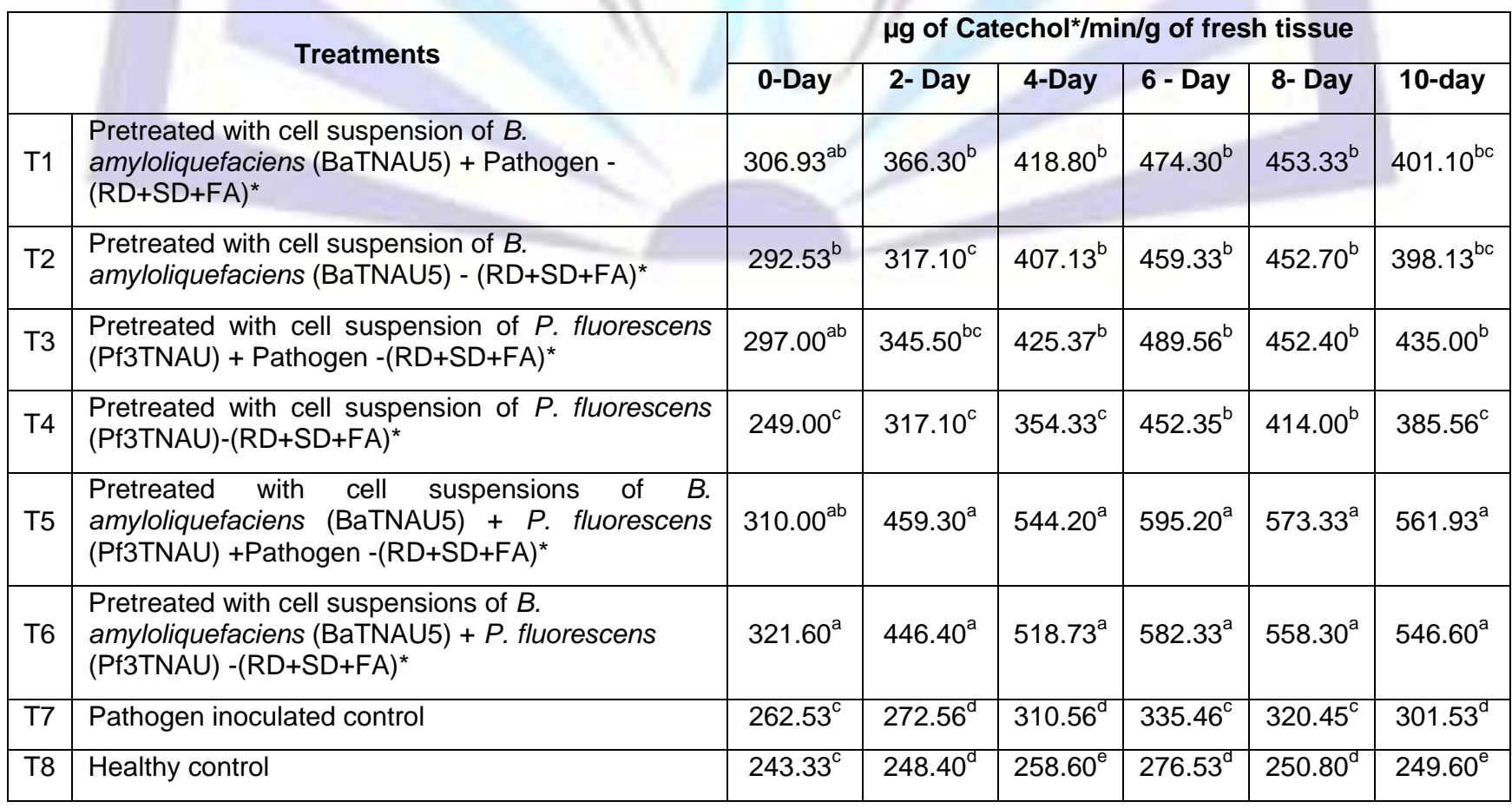


${ }^{*} \mathrm{RD}$ - Rhizome dipping, SD- Soil drenching, FA- Foliar application. *Values are the mean of three replications. In a column, means followed by common letters are not significantly different at the $5 \%$ level by DMRT.

\section{Catalase}

The induction of catalase increased in the cell suspension of $B$. amyloliquefaciens and $P$. fluorescens treated rhizome plants challenged with the pathogen. The induction started to increase from fourth day and recorded maximum at sixth day (3.78) after challenge inoculation and the activity was maintained at higher levels throughout the experimental period. Plants inoculated with the pathogen alone had comparatively less catalase (1.35) activity (Table 7).

Table 7. Induction of catalase activity in turmeric plants upon treatment with endophytic PGPRs strains challenged with $C$. capsici under glass house conditions

\begin{tabular}{|c|c|c|c|c|c|c|c|}
\hline \multirow{2}{*}{\multicolumn{2}{|c|}{ Treatments }} & \multicolumn{6}{|c|}{$\mu \mathrm{mol}$ of $\mathrm{H}_{2} \mathrm{O}_{2}$ consumed ${ }^{\star} / \mathrm{min} / \mathrm{g}$ fresh tissue } \\
\hline & & \multirow{2}{*}{$\begin{array}{l}\text { Day } \\
1.16^{\mathrm{a}}\end{array}$} & \multirow{2}{*}{$\begin{array}{c}\begin{array}{c}2- \\
\text { Day }\end{array} \\
1.78^{\mathrm{bc}}\end{array}$} & \multirow{2}{*}{$\begin{array}{c}\begin{array}{c}\text { 4- } \\
\text { Day }\end{array} \\
2.16^{c}\end{array}$} & \multirow{2}{*}{$\begin{array}{c}6- \\
\text { Day } \\
2.82^{b}\end{array}$} & \multirow{2}{*}{$\begin{array}{c}\begin{array}{c}8- \\
\text { Day }\end{array} \\
2.40^{\mathrm{C}}\end{array}$} & \multirow{2}{*}{$\begin{array}{l}\begin{array}{l}10- \\
\text { day }\end{array} \\
2.44^{\mathrm{c}}\end{array}$} \\
\hline T1 & $\begin{array}{l}\text { Pretreated with cell suspension of } B \text {. amyloliquefaciens } \\
\text { (BaTNAU5) + Pathogen }-(R D+S D+F A)^{*}\end{array}$ & & & & & & \\
\hline T2 & $\begin{array}{l}\text { Pretreated with cell suspension of } B \text {. amyloliquefaciens } \\
\text { (BaTNAU5) - (RD+SD+FA)* }\end{array}$ & $0.97^{\mathrm{C}}$ & $1.69^{\mathrm{C}}$ & $2.14^{\mathrm{C}}$ & $2.69^{b}$ & $2.21^{c}$ & $2.35^{\mathrm{c}}$ \\
\hline T3 & $\begin{array}{l}\text { Pretreated with cell suspension of } P \text {. fluorescens (Pf3TNAU) }+ \\
\text { Pathogen }-(\mathrm{RD}+\mathrm{SD}+\mathrm{FA})^{*}\end{array}$ & $0.89^{c}$ & $1.35^{d}$ & $1.71^{d}$ & $2.24^{c}$ & $1.91^{d}$ & $1.94^{\mathrm{d}}$ \\
\hline $\mathrm{T} 4$ & $\begin{array}{l}\text { Pretreated with cell suspension of } P \text {. fluorescens (Pf3TNAU)- } \\
(R D+S D+F A)^{*}\end{array}$ & $0.67^{\text {de }}$ & $0.92^{\mathrm{e}}$ & $1.57^{d}$ & $2.73^{b}$ & $2.36^{c}$ & $2.40^{\circ}$ \\
\hline T5 & $\begin{array}{l}\text { Pretreated with cell suspensions of } B \text {. amyloliquefaciens } \\
(\text { BaTNAU5) }+P \text {. fluorescens (Pf3TNAU) +Pathogen - } \\
(\mathrm{RD}+\mathrm{SD}+\mathrm{FA})^{*}\end{array}$ & $1.06^{b}$ & $2.01^{a}$ & $3.16^{\mathrm{a}}$ & $3.78^{a}$ & $3.44^{\mathrm{a}}$ & $3.47^{\mathrm{a}}$ \\
\hline T6 & $\begin{array}{l}\text { Pretreated with cell suspensions of } B \text {. amyloliquefaciens } \\
\text { (BaTNAU5) }+P . \text { fluorescens (Pf3TNAU) -(RD+SD+FA) }\end{array}$ & $1.18^{\mathrm{a}}$ & $1.89^{\mathrm{ab}}$ & $2.45^{b}$ & $3.56^{a}$ & $3.01^{b}$ & $2.94^{b}$ \\
\hline T7 & Pathogen inoculated control & $0.64^{\mathrm{e}}$ & $0.72^{\dagger}$ & $0.94^{\mathrm{e}}$ & $1.35^{\mathrm{d}}$ & $1.24^{\mathrm{e}}$ & $1.11^{\mathrm{e}}$ \\
\hline T8 & Healthy control & $0.75^{\mathrm{d}}$ & $0.79^{\mathrm{et}}$ & $0.85^{\mathrm{e}}$ & $0.88^{\mathrm{e}}$ & $0.72^{1}$ & $0.74^{\top}$ \\
\hline
\end{tabular}

${ }^{*} \mathrm{RD}$ - Rhizome dipping, SD- Soil drenching, FA- Foliar application. *Values are the mean of three replications. In a column, means followed by common letters are not significantly different at the $5 \%$ level by DMRT.

\section{Native PAGE Analysis Of Isoforms Pattern Of Peroxidase And Poly Phenol Oxidase}

Native poly acrylamide gel electrophoresis (PAGE) analysis revealed that seven POD isoforms designated as PO1 to PO7 were recorded in cell suspension of $B$. amyloliquefaciens (BaTNAU5) $+P$. fluorescens (Pf3TNAU) treated plants challenged with the pathogen. The expression of isoform $\mathrm{PO} 3$ and $\mathrm{PO} 4$ was more prominent in $B$. amyloliquefaciens and $P$. fluorescens treated plants challenged with the pathogen, when compared with other treatments. Moreover, other four constitutive isoforms (PO1, PO2, PO3 and PO4) was expressed at higher levels compared with untreated control (Fig. 1)

The differential expressions of four PPO isoforms (PPO1, PPO2, PPO3 and PPO4) were recorded in turmeric plants treated with cell suspension of $B$. amyloliquefaciens (BaTNAU5) $+P$. fluorescens (Pf3TNAU) challenged with the pathogen. The PPO2 and PPO3 were the newly induced isoforms in the bacterized treatment challenged with the pathogen. The differential expression of PPO1, PPO2 and PPO4 were absent in the healthy and inoculated control (Fig. 2) 
Figure 1 \& Figure 2. Differential expression of Peroxidase (PO) and PolyPhenol Oxidase (PPO) isoforms in PGPRs treated turmeric plants challenged with $C$. capsici.

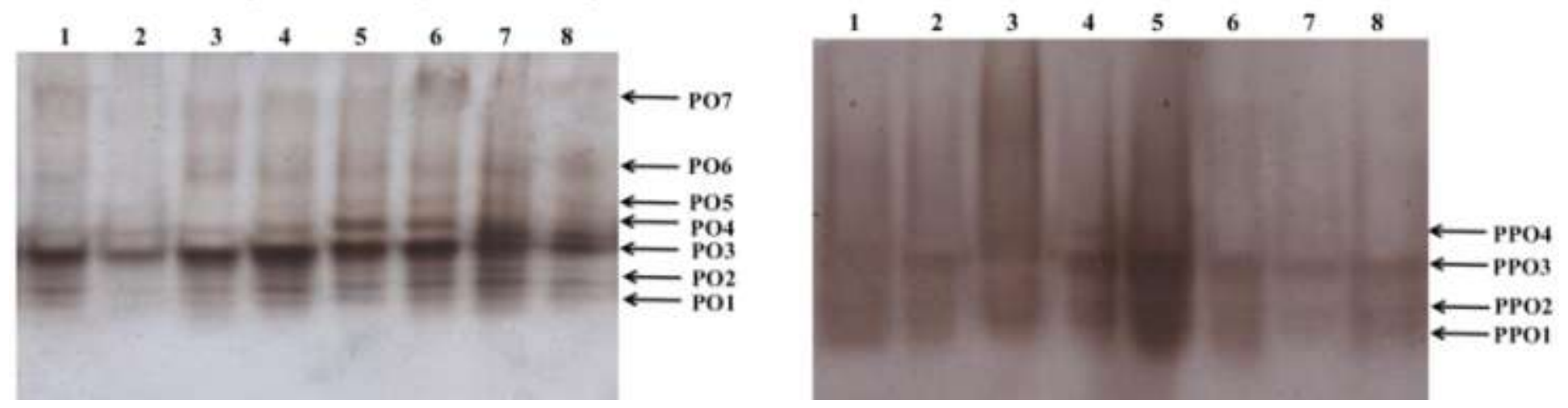

T1 - Pretreated with cell suspension of $B$. amyloliquefaciens + Pathogen

T2 - Pretreated with cell suspension of $B$. amyloliquefaciens + Pathogen

T3- Pretreated with cell suspension of $P$. fluorescens (Pf3TNAU) + Pathogen

T4- Pretreated with cell suspension of $P$. fluorescens (Pf3TNAU)

T5- Pretreated with cell suspensions of $B$. amyloliquefaciens (BaTNAU5) $+P$. fluorescens (Pf3TNAU) +Pathogen

T6 - Pretreated with cell suspensions of $B$. amyloliquefaciens (BaTNAU5) $+P$. fluorescens (Pf3TNAU)

T7- Pathogen inoculated control

T8 - Healthy control

\section{SDS-PAGE Analysis of Crude Protein of PGPR Treated Turmeric Plants Challenged C. Capsici}

The induced protein banding pattern was investigated from the turmeric plants treated with cell suspension of $B$. amyloliquefaciens (BaTNAU5) $+P$. fluorescens (Pf3TNAU) challenged with $C$. capsici. The banding pattern of protein was predominant in the treatment with rhizome dipping, soil drenching and foliar spray of cell suspension of $B$. amyloliquefaciens and $P$. fluorescens challenged with the pathogen. The proteins of $14,29,35$ and $68 \mathrm{kDa}$ were expressed in irrespective of the treatments. However, $35 \mathrm{kDa}$ and $43 \mathrm{KDa}$ proteins were expressed in high intensity in the plants applied with cell suspension of $B$. amyloliquefaciens and $P$. fluorescens (Fig. 3)

\section{Western Blot Analysis}

The crude proteins from PGPR inoculated turmeric leaves challenged with $C$. capsici at different time intervals were analyzed by Western blot analysis using barley chitinase antiserum. Upon treatment with $B$. amyloliquefaciens (BaTNAU5) and $P$. fluorescens (Pf3TNAU) challenged with $C$. capsici, a chitinase with an apparent molecular weight of $28 \mathrm{kDa}$ was induced four days after treatment (Fig. 4).

Figure 3. SDS PAGE analysis of induced proteins from turmeric in response to treatment with PGPRs and C. capsici

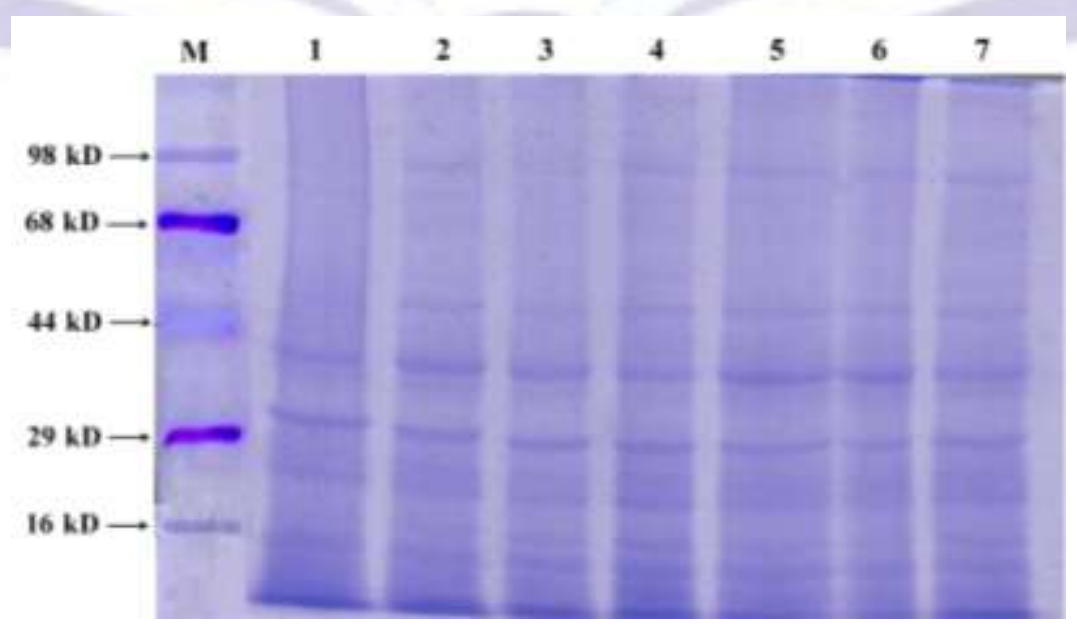


Figure 4. Western blot analysis of chitinase isoforms expression in PGPRs treated turmeric plants challenged with C. capsici

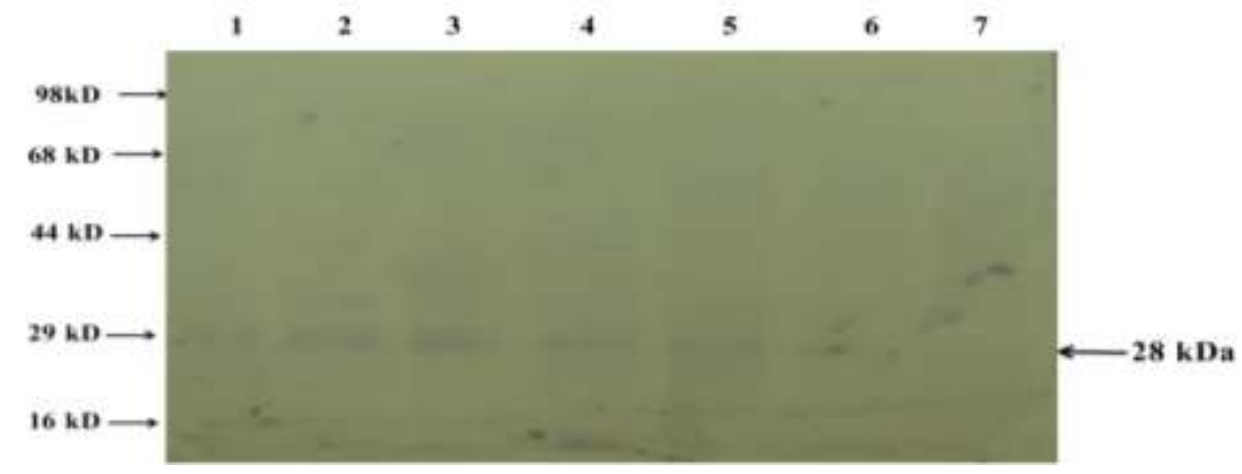

T1 - Pretreated with cell suspension of $B$. amyloliquefaciens + Pathogen

T2 - Pretreated with cell suspension of $B$. amyloliquefaciens + Pathogen

T3- Pretreated with cell suspension of $P$. fluorescens (Pf3TNAU) + Pathogen

T4- Pretreated with cell suspension of $P$. fluorescens (Pf3TNAU)

T5- Pretreated with cell suspensions of $B$. amyloliquefaciens (BaTNAU5) $+P$. fluorescens (Pf3TNAU) +Pathogen

T6 - Pretreated with cell suspensions of $B$. amyloliquefaciens (BaTNAU5) $+P$. fluorescens (Pf3TNAU)

T7- Pathogen inoculated control

\section{DISCUSSION}

Plants have several lines of defense against invading pathogens including preformed barriers and induced responses. It is well known that the defense genes are inducible and appropriate stimuli or signals are needed to activate in the plants. Induced resistance is a state of enhanced defensive capacity against broad spectrum of pests and pathogens developed by a plant [4]. POD, PPO, and PAL are three important defense-related enzymes. In most cases, the enhanced activities of POD, PPO and PAL in plant tissue are positively associated with induced systemic resistance and plant disease suppression [13].

Peroxidase represents a component of an early response in plants to pathogen attack and plays a key role in the biosynthesis of lignin which limits the extent of pathogen spread [26]. The products of this enzyme in the presence of hydrogen donor and hydrogen peroxide have antimicrobial activity and even antiviral activity [27]. Increased peroxidase (PO) has been observed in a number of resistant interaction involving plant pathogenic fungi, bacteria and virus [28]. In the present study, the activity of peroxidase was two folds greater than the uninoculated control in $B$. amyloliquefaciens and $P$. fluorescens treated plants. Similarly increased activity of cell wall bound peroxidase has been reported in different plants such as cucumber [28], rice [29] and tomato [30]. Increased activities of PO were observed in $P$. chlororaphis isolate (BCA) and $B$. subtilis isolate (CBE4) treated hot pepper seedlings after challenge inoculation with the pathogen $P$. aphanidermatum [31]. However, cell suspension or its cell-free culture filtrate of $B$. amyloliquefaciens B014 induced an increased activities of defense-related enzymes phenylalanine ammonia lyase, peroxidase and polyphenol oxidase, when compared to control in Anthurium plants challenged with the blight pathogen Xanthomonas axonopodis pv. dieffenbachiae [32].

Present investigation on the induction of PPO revealed that, the activity of PPO increased upto 6 days in the turmeric plants bacterized with cell suspension of $B$. amyloliquefaciens through dipping of rhizome and soil drenching coupled with foliar application at $0.5 \%$ concentration, challenged with $C$. capsici. Our results were corroborated with earlier workers that, the strains of $B$. subtilis and $P$. fluorescens were able to induce increased activities of PPO upon challenge inoculation with $A$. alternata in watermelon [33]. [34] Mathiyazhagan et al. reported that the bacterial antagonist $B$. subtilis isolate (BSCBE4) induced three isoforms PO1, PO2, PO3 while only PO2 and PO3 was expressed in $P$. amarus treated with P. chlororaphis (PA23) challenged against the pathogen Corynespora cassicola. Similarly, increased PO and PPO activity has been shown in a number of incompatible interactions involving plant pathogenic fungi, bacteria and viruses [35]. The application of endophytic $B$. subtilis and $P$. fluorescens, singly and in combination in green house and field conditions were found to be effective in controlling the chilli Fusarium wilt disease by inducing systemic resistance (ISR) as evidenced by enhanced activities of PO, PPO, PAL, $\beta-1,3$, glucanase, chitinase and phenolic involved in the synthesis of phytolaexins thereby promoting the growth of plants [36].

Furthermore, interactions among the bacterial strains may have synergistic effects that could induce ISR and promote the growth of the plants [37]. Several literature have documented the use of biocontrol agents in combination was more effective for management of plant diseases and pathogens compared to individual agents [38]. However, synergistic effect of $P$. fluorescens and Beauveria bassiana which significantly increased the induction of pathogenesis related proteins and enzymatic activity of phenylalanine ammonia-lyase, peroxidase, polyphenol oxidase, chitinase, $\beta-1,3-g l u c a n a s e$, superoxide dismutase, catalase, lipoxygenase, and phenolics in groundnut plants upon challenged with Sclerotium rolfsii. 
During establishment of pathogen in the host tissues, PAL generally shows increased activity [9]. PAL serves as the precursors of lignin biosynthesis and other phenolic compounds that accumulate in response to infection [39]. PAL plays an important role in the biosynthesis of phenolic phytoalexins [40]. The increase in PAL activity indicates the activation of phenyl propanoid pathway. The product of PAL activity is trans-cinnamic acid which is an immediate precursor for the biosynthesis of SA, a signal molecule in systemic acquired resistance (SAR). The rhizome treatment and foliar spray with $P$. fluorescens activated the systematic resistance in the host cell to develop different defense mechanism against $C$. capsici in turmeric plant under field condition which fetched higher yield [41].

Plants produce active oxygen species (AOS) such as superoxide anion $\left(\mathrm{O}_{2}\right)$, hydrogen peroxide $\left(\mathrm{H}_{2} \mathrm{O}_{2}\right)$ and hydroxyl radical $(\mathrm{OH})$ as one of the earliest responses to attempted infection by pathogens [42]. Scavengers of active oxygen species like catalase (which catalyzes the decomposition of $\mathrm{H}_{2} \mathrm{O}_{2}$ ) and superoxide dismutase (which scavenges $\mathrm{O}^{-2}$ ) suppress the oxidative burst and inhibit tissue necrotization [43]. Production of reactive oxygen species (ROS), particularly $\mathrm{H}_{2} \mathrm{O}_{2}$ has repeatedly been associated with diverse plant pathogen and plant insect interactions [44]. Pseudomonas and Bacillus based rhizobacterial-mediated induction of defense enzymes like phenylalanine ammonia lyase, peroxidase, polyphenol oxidase, chitinase and $\beta-1,3$-glucanase to enhance the resistance of turmeric to Pythium aphanidermatum causing rhizome rot [45]. In the present investigation, SOD and catalase activities were more in the turmeric plants treated with combination of $B$. amyloliquefaciens (BaTNAU5) $+P$. fluorescens (Pf3TNAU) with pathogen than individual treatments. SOD, PO and catalase are antioxidant enzymes involved in the removal of reactive oxygen species. Among them SOD functions are the first line of plant defence against oxidative damage under various stress conditions [46]. SOD catalyzes the dismutation of $\mathrm{O}_{2}^{-}$to $\mathrm{H}_{2} \mathrm{O}_{2}$ and molecular oxygen. $\mathrm{H}_{2} \mathrm{O}_{2}$ causes degradation of cell membrane and many cellular macromolecules. To restrict its activity, peroxidase (PO) and catalase get activated simultaneously, which act as scavenging enzymes to destroy free radicals and $\mathrm{H}_{2} \mathrm{O}_{2}$. Both $\mathrm{SOD}$ and $\mathrm{PO}$ exhibit interrelationship where SOD provides substrate for the activation of PO [47].

Phenols play an important role in determining resistance or susceptibility of a host to parasite infection [7]. Lignin is the phenolic polymer which is difficult to be breached by pathogen and has been implicated in plant defense against pests and diseases [48]. The role of phenolic substances has been reported in several host-pathogen interactions [49]. In the present study, the induction of $\beta-1,3-g l u c a n a s e$ and phenols were found to be higher in biocontrol treated plants and six days after challenged inoculation [50]. Similarly, induction of $\beta-1$, 3-glucanase induce the systemic resistance by $P$. fluorescens strain $\mathrm{CHAO}$ in tobacco and $B$. pumilus isolates 203-6 and 203-7 induced $\beta-1$, 3-glucanase in sugar beet [51]. The present investigation confirms the earlier work. The inoculation of root rot pathogen Rhizoctonia spp. or anthracnose pathogen Colletotrichum lindimutheanum induced systemic resistance by induction of peroxidases, $\beta, 1-3$-glucanases, chitinases in the bean plants [52].

Accumulation of pathogenesis-related (PR) proteins is known to be associated with systemic acquired resistance (SAR) in plants [53]. Studies have shown that PR-proteins are also induced in plants upon treatment with P. fluorescens [54]. PRproteins like chitinase and $\beta-1,3$-glucanase have the potential to hydrolyze chitin and $\beta-1,3-g l u c a n$ respectively, which are major components of fungal cell walls. Moreover the chitinase and glucanase release elicitors from the walls of fungi which, in turn, stimulate various defense responses in plants [55]. Furthermore, it has been demonstrated that overexpression of chitinase in transgenic crop plants was associated with enhanced resistance to different fungal pathogens. Immunoblot analysis of protein extracts from $B$. amyloliquefaciens (BaTNAU5) and $P$. fluorescens (Pf3TNAU), treated plants in the present study revealed that a chitinase with an apparent molecular weight of $28 \mathrm{kDa}$ was induced three days after treatment. These results indicated that chitinase present at low or undetectable levels in control plants and are inducible after foliar application of $B$. amyloliquefaciens (BaTNAU5) and $P$. fluorescens (Pf3TNAU). Hence, it is also possible that increased resistance in turmeric due to foliar application of PGPR strains might be related to the accumulation of PR-proteins in addition to accumulation of phenolics.

These results suggest that selected biocontrol agents $B$. amyloliquefaciens (BaTNAU5) and $P$. fluorescens (Pf3TNAU) can be used as a source of induction of defence resistance mechanism in the plants against phytopathogens through activation of ethylene, jamonic acid and phenylpropanoid pathway in the host plant.

\section{ACKNOWLEDGEMENT}

The authors are grateful to the Department of Plant Pathology, Tamil Nadu Agricultural University, Coimbatore, for the support of chemicals and equipments for this research. The corresponding author thanks to Indian Council of Agricultural Research (ICAR), New Delhi, India awarded Senior Research Fellowship for the doctoral programme.

\section{REFERENCES}

[1] Anonymous, 2012 http//:www.indianspices.com. Spices Board Annual Report 2011-12. pp.36.

[2] Jagtap, G. P., Mali, A. K., and Dey, U. 2013 Bioefficacy of fungicides, bio-control agents and botanicals against leaf spot of turmeric incited by Colletortricum capsici. African journal of microbiology research. 7(18): 1865-1873.

[3] Egaas, E., Sandvik, M., Fjeld, E., Kallqvist, T., Goksyr, A., and Svensen, A. 1999 Some effects of the fungicide propiconazole on cytochrome P450 and glutathione S-transferase in brown trout (Salmo trutta). Comparative biochemistry and physiology. 122: 337-344.

[4] Van Loon, L. C., Bakker, P. A. H. M., and Pieterse, C. M. J. 1998 Systemic resistance induced by rhizosphere bacteria. Annual review of phytopathology. 36: 453-483. 
[5] Van Loon, L. C. 2007. Plant responses to plant growth-promoting rhizobacteria. European journal of plant pathology. 119: 243-254.

[6] Anand, T., Raguchander, T., Karthikeyan, G., Prakasam, V., and Samiyappan, R. 2007 Chemically and biologically mediated systemic resistance in cucumber (Cucumis sativus L.) against Pseudoperonospora cubensis and Erysiphe cichoracearum. Phytopathologia mediterranea. 46: 259-271.

[7] Vidhyasekaran, P. 1998 Physiology of disease resistance in plants. vol. I. CRC. press. Boca Raton, FL, 149p.

[8] Deborah, S. D., Palaniswami, A., and Velazhahan, R. 2001 Differential induction of chitinase and $\beta$ 1,3-glucanase in rice in response to inoculation with a pathogen (Rhizoctonia solani) and a non-pathogen (Pestalotia palmarum), Acta phytopathologica et entomologica hungarica. 36(1-2): 67-74.

[9] Senthilraja, G., Anand, T., Kennedy, J. S., Raguchander, T., and Samiyappan, R. 2013 Plant growth promoting rhizobacteria (PGPR) and entomopathogenic fungus bioformulation enhance the expression of defense enzymes and pathogenesis-related proteins in groundnut plants against leafminer insect and collar rot pathogen. Physiologica and molecular plant pathology. 82: 10-19.

[10] Jetiyanon, K., and Kloepper, J. W. 2002 Mixtures of plant growth-promoting rhizobacteria for induction of systemic resistance against multiple plant diseases. Biological control. 24: 285-291.

[11] Viswanathan, R., and Samiyappan, R. 2007 Siderophores and iron nutrition on the pseudomonas mediated antagonism against Colletotrichum falcatum in sugarcane. Sugar technology. 9(1): 57-60.

[12] Than, P. P., Jeewon, R., Hyde, K. D., Pongsupasamit, S., Mongkolporn, O., and Taylor, P. W. J. 2008 Characterization and pathogenicity of Colletotrichum species associated with anthracnose disease on chilli (Capsicum spp) in Thailand. Plant pathology. 57: 562-572.

[13] Hassan, M. A. E., Bereika, M. F. F., Abo-Elnaga, H. I. G., and Sallam, M. A. A. 2009 Direct antimicrobial activity and induction of systemic resistance in potato plants against bacterial wilt disease by plant extracts. Plant pathology journal. 25(4): 352-360.

[14] Bradford, M. 1976 A rapid and sensitive method for the quantification of microgram quantities of protein utilizing the principle of protein dye binding. Analytical biochemistry. 72: 248-250.

[15] Eshel, D., Beno-Moualem, D., Lorang, J. M., Dinoor, A., and Prusky, D. 2002 Induction of peroxidase during infection of unripe persimmon fruit by Alternaria alternata: a possible quiescence mechanism. Journal of Phytopathology. 150: 357-362.

[16] Gauillard, F., Richard-Forget, F., and Nicolas, J. 1993 New spectrophotometric assay for polyphenol oxidase activity. Analytical biochemistry. 215: 59-65.

[17] Silva, H. S. A., Romeiro, R. S., Macagnan, D., Halfeld-Vieira, B. A., Baracat-Pereira, M. C., and Mounteer, A. 2004 Rhizobacterial induction of systemic resistance in tomato plants: non-specific protection and increase in enzyme activities. Biological control. 29: 288-295.

[18] Pan, S. Q., Ye, X. S., and Kuc, J. 1991 Association of B-1, 3- glucanase activity and isoform pattern with systemic resistance to blue mold in tobacco induced by stem injection with Peronospora tabacina or leaf inoculation with tobacco mosaic virus. Physiology and molecular plant pathology. 39: 25-39.

[19] Belid El-Moshaty, F. I. B., Pike, S. M., Novacky, A. J., and Seghal, O. P. 1993 Lipid peroxidation and superoxide production in cowpea (Vigna unguiculata) leaves infected with tobacco ring spot virus or southern bean mosaic virus. Physiology and molecular plant pathology. 43: 109-119.

[20] Bray, H. G., and Thorpe, W. V. 1954 Analysis of phenolic compounds of interest in metabolism. Methods biochem anal. 1: 27-52.

[21] Dekock, P. C., Commisiong, K., Farmer, V. C., and Inkson, H. E. 1960 Interrelationships of catalase, peroxidase, hematin and chlorophyll. Plant physiology. 35: 599-604.

[22] Laemmli, U. K. 1970 Cleavage of structural proteins during the assembly of the head bacteriophage T4. Nature. 227: 680-684.

[23] Jayaraman, K. S., Ramanuja, M. N., Vijayarahavan, P. K., and Vaidyanathan, C. S. 1987 Studies on the purification of banana polyphenol oxidase. Food chemistry. 24: 203-217.

[24] Winston, S., Fuller, S., and Hurrel, J. 1987 Western blotting. In: Ausubel, F., Brent, R., Kingston, R., Moore, D., Smith, S. J. and Struhl, K. (eds): Current protocols in molecular biology. John Wiley, New York, NY. pp. 10.8.110.8.6.

[25] Gomez, K. A., and Gomez, A. A. 1984. Statistical Procedure for Agricultural Research. John Wiley and Sons, New York.

[26] Bruce, R. J., and West, C. A. 1989 Elicitation of lignin biosynthesis and isoperoxidase activity by pectic fragments in suspension cultures caster bean. Plant Physiology. 91: 889-897. 
[27] Van Loon, L. C., and Callow, J. A. 1983 Transcrption and translation in the diseased plant. In: Biochemical plant pathology (J.A. Callow, ed.). 385-414 pp.

[28] Chen, X. H., Koumoutsi, A., Scholz, R., and Borriss, R. 2009 More than anticipated production of antibiotics and other secondary metabolites by Bacillus amyloliquefaciens FZB42. Journal of molecular microbiology and biotechnology. 16: 1424.

[29] Reimers, P. J., Guo, A., and Leach, J. E. 1992 Increased activity of a cationic peroxidase associated with an incompatible interaction between Xanthomonas oryzae pv. oryzae and rice (Oryza sativa). Plant physiology. 99: 1044-1050.

[30] Mohan, L., Vijayan, P., and Kolattukudy, P. E. 1993 Development and tissue specific expression of a tomato anionic peroxidase (tap1) gene by a minimal promoter with wound and pathogen induction by an additional 5 ' flanking region. Plant molecular biology. 22: 75-90.

[31] Nakkeeran, S., Kavitha, K., Chandrasekar, G., Renukadevi, P., and Fernando, W. G. D. 2006 Induction of plant defense compounds by Pseudomonas chlororaphis PA23 and Bacillus subtilis BSCBE4 in controlling damping-off of hot pepper caused by Pythium aphanidermatum. Biocontrol science and technology. 16(4): 403-416.

[32] Li, S. B., Mao, F., Zhou, R. C., and Juan, H. 2012 Characterization and evaluation of the endophytic Bacillus B014 as a potential biocontrol agent for the control of Xanthomonas axonopodis pv. dieffenbachiae induced blight of Anthurium. Biological control. 63: 9-16.

[33] Uma Maheswari, C., Sankaralingam, A., and Nallathambi, P. 2009 Induced systemic resistance in watermelon by biocontrol agents against Alternaria alternata. Archives of phytopathology and plant protection. 42(12): 1187-1195.

[34] Mathiyazhagan, S., Kavitha, K., Nakkeeran, S., Chandrasekar, G., Manian, K., Renukadevi, P., Krishnamoorthy, A. S., and Fernando, W. G. D. 2004 PGPR mediated management of stem blight of Phyllanthus amarus (Schum and Thonn) caused by Corynespora cassiicola (Berk and Curt). Archives of phytopathology and plant protection. 37: 183-199.

[35] Saravanakumar, D., Vijayakumar, C., Kumar, N., and Samiyappan, R. 2007 PGPR induced defense responses in the tea plant against blister blight disease. Crop protection. 26: 556-565.

[36] Sundaramoorthy, S., Raguchander, T., Ragupathi, N., and Samiyappan, R. 2012 Combinational effect of endophytic and plant growth promoting rhizobacteria against wilt disease of Capsicum annum L. caused by Fusarium solani. Biological control. 60: 59-67.

[37] Latha, P., Anand, T., Ragupathi, N., Prakasam, V., and Samiyappan, R. 2009 Antimicrobial activity of plant extracts and induction of systemic resistance in tomato plants by mixtures of PGPR strains and Zimmu leaf extract against Alternaria solani. Biological control. 50: 85-93.

[38] Young, C. K., Hyunchae, J., Yong, K. K., and Seur Kee, P. 2008 An effective biocontrol bioformulation against Phytophthora blight of pepper using growth mixtures of combined chitinolytic bacteria under different field conditions. European journal of plant pathology. 120: 373-382.

[39] Klessig, D. F., and Malamy, A. 1994 The salicylic acid signalling in plants. Plant molecular biology. 26: 1439-1458.

[40] Daayf, F., Schmitt, A., and Belanger, R. R. 1997 Evidence of phytoalexins in cucumber leaves infected with powdery mildew following treatment with leaf extracts of Reynoutriasa chalinensis. Plant physiology. 113: 719-727.

[41] Ramkumar, S., Prabhakar, S., and Pandurangan, M. 2012 Role of antagonistic microbe Pseudomonas fluorescens on Colletotrichum capsici infecting Curcuma longa. Journal of plant pathology and microbiology. 3: 7-10.

[42] Grant, J. J., and Loake, G. J. 2000. Role of reactive oxygen intermediates and cognate redox signalling in disease resistance. Plant Physiology, 124: 2-9.

[43] Vera-Estrella, R., Blumwald, E., and Higgins, V. J. 1993. Non-specific glycopeptides elicitors of Cladosporium fulvum: Evidence for involvement of active oxygen species in elicitor-induced effects on tomato cell suspension. Physiology molecular plant pathology. 42: 9-12.

[44] Orozco-Cardenas, M. L., Narvaez-Vasquez, J., and Ryan, C. A. 2001 Hydrogen peroxide acts as a second messenger for the induction of defense genes in tomato plants in response to wounding, systemin and methyl jasmonate. Plant cell. 13: 179-191.

[45] Kavitha, K., Nakkeeran, S. and Chandrasekar, G. 2012 Rhizobacterial mediated induction of defense enzymes to enhance the resistance of turmeric (Curcuma longa $\mathrm{L}$ ) to Pythium aphanidermatum causing rhizome rot. Archives of phytopathology and plant protection. 45(2): 199-219.

[46] Alscher, R. G., Erturk, N., and Heath, L. 2002 Role of superoxide dismutase (SODs) in controlling oxidative stress in plants. Journal of experimental botany. 72: 1331-1341.

[47] Van Loon, L. C. 1997 Induced resistance in plants and the role of pathogenesis-related proteins. European journal of plant pathology. 103(7): 53-65. 
[48] Nicholson, R. L., and Hammerschmidt, R. 1992 Phenolic compound and their role in disease resistance. Annual review phytopathology. 30: 369-389.

[49] Ramamoorthy, V., and Samiyappan, R. 2001 Induction of defense-related genes in Pseudomonas fluorescens treated chilli plants in response to infection by Colletotrichum capsici. Journal of mycology and plant pathology. 31 : 146-155.

[50] Maurhofer, M., Hase, C., Meuwly, P., Me'traux, J. P., and De'fago, G. 1994 Induction of systemic resistance of tobacco to tobacco necrosis virus by the root colonizing Pseudomonas fluorescens strain CHA0: Influence of the gacA gene and of pyoverdine production. Phytopathology. 84(1): 39-46.

[51] Bargabus, R. L., Zidack, N. K., Sherwood, J. W., and Jacobsen, B. J. 2002. Characterization of systemic resistance in sugarbeet elicited by a non-pathogenic, phyllosphere colonizing Bacillus mycoides, biological control agent. Physiological and molecular plant pathology. 61: 289-298.

[52] Xue, L., Charest, P. M., and Jabaji-Hare, S. H. 1998 Systemic induction of peroxidases, $\beta-1,3$ glucanases, chitinases, and resistance in bean plants by binucleate Rhizoctonia species. Biological control. 88(4): 359-365.

[53] Ryals, J. A., Neuenschwander, U. H., Willits, M. G., Molina, A., Steiner, H. Y., and Hunt, M.D. 1996 Systemic acquired resistance. Plant cell. 8: 1809-1819.

[54] M'Piga, P., Belanger, R. R., Paulitz, T. C., and Benhamou, N. 1997 Increased resistance to Fusarium oxysporum f.sp. radicis lycopersici in tomato plants treated with the endophytic bacterium Pseudomonas fluorescens strain 6328. Physiological and molecular plant pathology. 50: 301-320.

[55] Ren, Y. Y., and West, C. A. 1992 Elicitation of diterpene biosynthesis in rice (Oryza sativa L.) by chitin. Plant physiology 99: 1169-1178.

\section{Author' biography with Photo}

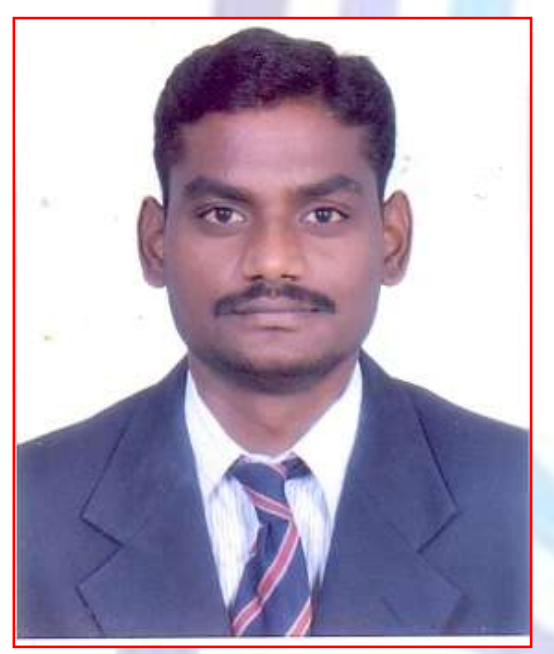

Dr. P. Adhipathi completed his Ph.D in Plant Pathology from Tamil Nadu Agricultural University, Coimbatore, India. He was awarded Junior Research Fellowship (2007-09) for Master degree and Senior Research Fellowship (20102013) for the Doctorate Programme by Indian Council of Agricultural Research, New Delhi, India. He has published 7 papers in the reputed peer-reviewed journals. He is the fellow of Indian Science Congress Association, Indian Society of Mycology and Plant Pathology, Plant Protection Association of India since 2013. His field of research are: Molecular Plant Pathology, Plant Disease Resistance and Biological Control. 